\title{
A Critique of Undergraduate Students' Writing Skill in an ESL Setting: Samples from the Federal University of Agriculture, Abeokuta, Nigeria
}

\author{
Helen A. Bodunde ${ }^{1} \&$ Bosede S. Sotiloye ${ }^{1, *}$ \\ ${ }^{1}$ Department of Communication and General Studies, Federal University of Agriculture, P.M.B. 2240, Abeokuta, \\ Nigeria \\ *Corresponding author: Department of Communication and General Studies, Federal University of Agriculture, \\ P.M.B. 2240, Abeokuta, Nigeria. E-mail: bssotiloye@yahoo.com
}

Received: April 1, 2013

Accepted: April 26, $2013 \quad$ Online Published: June 9, 2013

doi:10.5430/wjel.v3n2p10

URL: http://dx.doi.org/10.5430/wjel.v3n2p10

\begin{abstract}
The importance of writing cuts across all levels of education. Its effectiveness hinges on the ability to use the grammar of language appropriately especially in a second language (SL) situation. This paper compares the writing skill in English Language of eighty 100 level students and forty of those in 500 level core Agriculture colleges who were randomly selected for grammatical assessment in a Nigerian University. The research was carried out after both groups had gone through English and Communication Skills courses. The results show that students have problems with almost all aspects of grammar - tense, punctuation, spelling, concord, abbreviation, preposition, and word amalgamation. At the 100 level, tense and spelling errors were the most frequent while punctuation and tense errors were most prominent in 500 level scripts. Tense errors were common to both groups as a result of negative transfer from the first language (L1), though the environment in which they occurred differ. The study also reveals an important relationship between a mastery of the speaking skill and effective writing. The implications of the findings on the teaching and learning processes were discussed and suggestions were made on how to improve students' writing capability.
\end{abstract}

Keywords: writing skill; first language; second language; negative transfer; English and Communication Skills; teaching and learning processes

\section{Introduction}

Writing is one of the four skills of language. It is the most used skill in assessing students' performance in virtually all courses in tertiary institutions. It is equally the most used in correspondences in ministries, industries, and parastatals. The above roles, therefore, emphasize the importance of the skill and the need to develop it from the basic (primary) to the highest (tertiary) level. Generally, the emphasis at the tertiary level, is highly justified because the opportunity may not come again having missed it at the primary and secondary school levels. In particular, the importance of the writing skill in specialized or non-conventional universities cannot be over-emphasized. Students need the skill from 100 level to take notes, undertake assignments, write report, term papers, and projects, and also to answer questions in examinations. It is essential for professional success after graduation. It is an assertion that the importance of writing is not unique to liberal arts or social sciences alone but is also germane in science and technology courses. In this light, a 1965 study revealed that engineering graduates rated technical writing as the second highest skill (Middendorf 1980; also cited in Huckin \& Oslen 1984). This is corroborated in a study by Osagbemi and Bodunde (1998), in which Agriculture students rated writing as the highest skill required for their academic pursuit.

The effectiveness of any writing is determined by grammatical correctness (Jekins, Jordan \& Weiland, 1993) as syntactic ambivalence leads to semantic ambiguity. It implies that good and meaningful composition goes beyond organization, but the correctness of the grammatical structures. Engeber (1995) cited in Agustin Llach (2012), reiterates that language performance is usually assessed based on its communicability which is a reflection of the presence or absence of errors. Adogwa (1992), Bodunde (2009 and Olanipekun) and, Daras and Subramaniam (2009) have reported students' errors in almost every aspect of grammar. Vaughan (2011) identified inability to differentiate 
between monothong and diphthong as a common error in L2 learners' writing. The persistence in error calls for the elongation of English and Communication Skill (ECS) course (Adogwa 1992, Bodunde 2005).

There have been divergent opinions concerning the content of undergraduate writing. Some claim that content-based writing may be more successful than general purpose English in developing writing skills (Shuh, 1986; Snow \& Brinton, 1988) while others argue that discipline-specific writing should not be taught (Spack,1988). The topic of the writing material may not really determine the standard of students' writing. This is because in formal / informal, and professional / non-professional writing, the correctness of the grammar and the organization of the content emphasize the aptitude and ability (content and expression) of the writer. Abdullah et.al (2011) postulates that students' writing strategies determine the writing output. The clarity of a piece of writing goes a long way in knowledge dissemination.

The frequent and increasing comments on the writing ability of undergraduates and even graduates of second language learners of English have been a thing of concern to teachers of English, and the content teachers. For instance, Use of English lecturers have always been challenged when students make faulty expressions. Also, problems in writing are very common in the theses of final year students and this makes the content teachers to cast aspersions on the relevance of the Use of English course. Comments such as these, point to students' shortcomings in the knowledge of English Language, especially in L2 writing process which is a complex development influenced by many factors such as culture, community language, and social environment (Ortmeier-Hooper \& Schwartz, 2010). The influence of L1 on the speaking and writing skills of L2 learners has, in line with numerous other researchers, been established by Ancker (2000) Sotiloye (2007), Bodunde (2008), Titchenelle (2011), and Crompton (2011). The paucity of L2 learners' knowledge of the language, coupled with its complexity has also compounded students' writing capacity (Lengo 1995, Sotiloye \& Bodunde (in press)).

Some researchers like Oguntuase (2003), Aborisade (2003), Adelabu et.al (2004), and Onukaogu (2005) have attempted to look at the problems encountered by students in acquiring and writing English as a second language using various pre-determined parameters. The present study delves further into the analysis of the writing of undergraduates in non-conventional universities using the Federal University of Agriculture, Abeokuta (FUNAAB) as a case study.

It is aimed at finding out the level of students' competence in the use of the English language for academic writing at the end of the first year having gone through the Use of English course where rudiments of grammatical structures, mechanics, and vocabulary acquisition have been learnt. This is compared with that of the students of last year of study, who, after the Use of English course, had for four years been acquainted with the English language as medium of instruction and examination. It is also an attempt to know the grammatical needs of the students through their expressions in writing with the aim of contributing to the curriculum of English and Communication Skill (ECS) and facilitating the teaching and learning processes. In line with Ellis' (1996) submission, identified errors are valuable and useful in determining the remedies, and also to achieve successful performance.

\section{Objectives}

The objectives of this study are to

1) find out the level of the competence of first year Agriculture students in the Use of English language for academic writing

2) find out the level of the competence of final year Agriculture students in the Use of English language for academic writing

3) compare the grammatical error types identified in the writings of first and final year Agriculture students

\section{Hypothesis}

The null hypothesis states that there is no significant difference between the grammatical errors committed in the writing of first and final year Agriculture students.

\section{Methodology}

A random sampling of 80 examination scripts from 80 core Agriculture students who were in the first year in the 2009/10 session in (FUNAAB) was taken. The sample forms 10\% of 100 level students of core colleges of 
Agriculture, namely College of Agricultural Management and Rural Development (COLAMRUD), College of Animal Science and Livestock Production (COLANIM), and College of Plant Science and Crop Production (COLPLANT) who sat for GNS 101 titled English and Communication Skills (ECS) examinations. The assessment was based on a compulsory question which asked the students to write a formal letter to the Vice-Chancellor to exonerate them from a crisis that occurred on the campus which degenerated to a student protest. In addition, a random sampling of 40 scripts from the core agricultural students in the above colleges who were in 500 level in the session under consideration was also taken. The sample scripts were selected from HRT 502 (Crops Husbandry), a university-wide course for students from the different colleges. The 500 level students were asked to write an essay on how to revive a diseased cocoa plantation. A compulsory question in the paper was assessed. The writing calls for specialized registers in the field of agriculture. It is assumed that at this level, all the students should be conversant with the use of appropriate registers in the field. The sample choice of 100 and 500 levels is to establish the level of the writing competence of the undergraduates at 100 and 500 levels, both sets having undergone the English and Communication Skills course in which they were exposed to all the four skills of language, writing inclusive. It is assumed that the 500 level students who had applied the skills to academic work for four sessions ought to have mastered the rudiments of English thereby having a better grasp and more appropriate use of the language in all context, including examinations which call for effective performance.

The errors which involved grammar (rules of verbs, agreement/concord, pronoun), mechanics (spelling, punctuation), and word choice (vocabulary) were analysed in simple percentages and presented in tables. A t-test analysis was also carried out on the data.

\section{Results and Discussion}

The errors of 100 level students are presented first, followed by those of 500 level students. A comparison of the two is later made, and the result of the hypothesis thereafter.

\subsection{Analysis of Errors of the 100 Level Students}

Errors identified in the scripts of first year students are in their use of tense, spelling, concord, punctuation, abbreviation, wrong amalgamation of words, and wrong use of preposition. The frequency and percentage of the occurrence of the errors are presented in Table 1.

Table 1: Classification of 100 Level Agriculture Students' Errors

\begin{tabular}{llll}
\hline Type of Error & $\begin{array}{l}\text { Number of } \\
\text { Students }\end{array}$ & $\begin{array}{c}\text { Frequency } \\
\text { (F) }\end{array}$ & \% \\
\hline Tense & 80 & 30 & 37.5 \\
Spelling & 80 & 45 & 56.25 \\
Concord & 80 & 26 & 32.5 \\
Punctuation & 80 & 23 & 28.75 \\
Abbreviation & 80 & 10 & 12.5 \\
Preposition & 80 & 10 & 12.5 \\
Wrong Amalgamation. & 80 & 3 & 3.75 \\
\hline
\end{tabular}

From Table 1, spelling error tops the list. Examples of such errors are indicated below:

$\checkmark$ Our names where written down. (were)

$\checkmark$ I will be greatful if this request will be granted. (grateful)

$\checkmark$ My prooves are as follows... (proofs)

$\checkmark$ I found it a little bit difficult to belief him. (believe)

$\checkmark$ I will be glad if I am decleared innocent. (declared)

- The avoc done by the students is enormous. (havoc)

$\checkmark$ It was quiet an unfortunate incident. (quite) 
$\checkmark \quad \mathrm{He}$ as sustained injury. (has)

$\checkmark$ I was not in school that faithful day. (fateful)

These errors could be traced to wrong pronunciation. It shows the effect of speech on writing. The errors border on inability of students to differentiate between monothongs and diphthong as shown in the first two examples. Vaughan 2011 points out that L2 learners' inadequacy in this area is a common error. The vowel in where is a diphthong /eə / as opposed to the monothong / $\partial$ / in were. There is also the error in the use of $v$ for $f$ as a result of confusion of the voiceless and voiced labio - dental fricative / f / with the voiced one / v / or vice versa as is the case with prooves instead of proofs, and belief for believe. It is also the effect of wrong pronunciation that resulted in the omission of the initial consonant of havoc in the sixth example above.

Other phonological errors identified can be traced to the inconsistencies and complexities in the pronunciation of the English language and students' failure to master these (Sotiloye and Bodunde (in press)). For example, the dark or silent letter is a major cause in the following errors:

$\checkmark$ The mass [sic] erected has a cycological effect on the students. (psychological)

$\checkmark$ I will not tanish the image of the family. (tarnish)

$\checkmark$ I was reading for examination sheduled for ... (scheduled)

Other spelling errors, the source of which is not easily identifiable, are:

$\checkmark$ The issue is that of MTN officiers not willing to cooperate. (officer)

$\checkmark$ I hereby declair that I was not among the student (sic)... (declare)

Malapropisms are also identified:

$\checkmark$ Then students bit there teachers. (beat their)

$\checkmark$ I was knew in the system. (new)

A total of $37.5 \%$ of the research subjects had tense errors. The most common being the wrong use of to-infinitive with the past form:

$\checkmark$ I decided to ran for my life. (run)

$\checkmark$ I made a phone call to my parents in order to informed them about the problem. (inform)

$\checkmark$ I only came to discovered that the students gathered in the library. (discover)

$\checkmark$ I decided to traveled back home. (travel)

$\checkmark$ How to dealt with the school authority was emphasized. (deal)

The sentences show that the students have not grasped the correct use of to-infinitive. There are also tense errors due to the repetition of the use of the past tense which exposes the students' weakness in the use of the verb to do:

$\checkmark$ I did not involved myself in the crisis. (involve)

$\checkmark$ I did not joined the demonstration. (join)

Another tense error identified is the wrong use of present tense for past:

$\checkmark$ The crisis which occur in September affects me. (occurred; affected)

$\checkmark$ I rush down to the library. (rushed)

$\checkmark$ He has not move in the afternoon. (moved)

$\checkmark$ I arrive Abeokuta. (arrived)

$\checkmark$ This happen precisely on Tuesday. (happened)

$\checkmark$ Previous to that day, I have travelled to Lagos. (had)

The above errors do not totally mar comprehension but the rules of English grammar are violated.

Furthermore, $25 \%$ of the students made concord errors that can be classified as disagreement between subject and verb, and also between demonstrative determiners and nouns. Examples of the former are:

$\checkmark$ The pictures is attached to this letter. (are)

$\checkmark$ The Student Union executives was aware of the plan. (executive members were) 
$\checkmark$ The issue of MTN officiers [sic] were taking (sic) seriously. (was)

$\checkmark$ A lot of thing have been damaged. (things had)

while that of the latter are:

$\checkmark$ These great University is ours. (This)

$\vartheta$ One of the major cause of the crisis is the mast. (causes)

$\checkmark$ Some of the student carrying stick beat their leacturers[sic]... (students)

$\checkmark$ These evil act of the student carried out is bad. (This)

The non-mastery of some grammatical structures, inability to distinguish between the singular and plural forms of the demonstratives, may have contributed to the error.

Punctuation error ranked fourth with $28.75 \%$. Wrong capitalization forms the bulk of the error manifesting mostly as intrusion of capital letters in the middle of sentences:

$\checkmark$ May I seek for your Indulgence concerning the situation.

$\forall$ The students demonstrated violent behaviour in the campus, In which there was no record of such even before...

$\checkmark$ Some of my friends rushed to my area and Informed me about the crisis.

Another punctuation problem is wrong use of punctuation marks that hinder the flow of thought or idea presented. Examples of such are:

$\checkmark$ I hereby, ${ }_{2}$ plead to be exonerated.

$\checkmark$ I did that in order, to prevent the problem.

$\checkmark$ Being an 100 level student; I reside in the school hostel.

$\checkmark$ I would be very grateful if I am being considered as a good student of this school; through my explanation.

The intrusive comma and semi-colon marks show that the students have not really understood the concept of temporary stop in writing. It is incorrect to separate a subject from its verb with a comma as done in the first two examples above. A comma, instead of a semi-colon, would have been appropriate in the third sentence. The use of a semi-colon in the last sentence is not necessary since semi-colons are usually used to join the clauses of a compound sentence without a conjunction.

Errors bordering on the inappropriate choice of prepositions were made by $2.5 \%$ of the students as in the following examples:

- I was reading for examination scheduled on Tuesday

$\checkmark$ My parents praised me to leaving the school premises.

Sometimes prepositions are used where not necessary as in

$\checkmark$ The mast erected has a cychological [sic] effect that comprises of many things.

$\checkmark$ I arrived in Abeokuta.

The first two examples should take for while the last two should not take any preposition. The verb comprise is often confused with consist that takes of. The last example portrays a sentence that is translated from the first language (Yoruba) to the second language. The sentence in Yoruba is Mo de si Abeokuta literally translated as I arrive to Abeokuta. The student, probably aware that it is nonsensical to have I arrive to Abeokuta, substitutes to with in. This is syntactic interference since a removal of the preposition in his Mother Tongue (MT), Mo de Abeokuta, would produce another meaning I got to Abeokuta (may be on my way to another town). This is a case of negative transfer of MT knowledge to the Target Language (TL). Transfer of knowledge is common in language learning but when it is negative, it has to be addressed promptly. It is a thing of concern at the tertiary level when students translate from the first language (L1) to the second language (L2) without taking cognizance of the difference in the structures of the languages involved. Errors caused by negative transfer from L1 have been reported in some other studies (Titchenelle, 2011 and Crompton, 2011).

The use of abbreviations and even unconventional ones in a formal writing are also noticed. $12.5 \%$ of the students committed such errors as shown below: 
$\checkmark$ The crisis was due to $\underline{\mathrm{d}}$ unruling[sic] attitude of $\underline{\mathrm{d}}$ students. (the)

$\checkmark$ I am ready to support you with any useful information to yr investigation. (your)

$\checkmark$ I want to say that a was not in the school and town. (I)

$\checkmark$ I came \& I did not see them. (and)

From the errors, it shows that some students fail to distinguish between formal and informal writings. Some of the errors could also be traced to the influence of informal writing such as text messages in Global System for Mobile Communication (GSM) device and note-taking techniques during lectures. The laisser-faire attitude of undergraduates towards academic writings is glaring from the kinds of errors made here.

Wrong amalgamation of words is also noticed with 3.75\% of the students committing the error. This shows that they do not have a good grasp of word formation system of the language. Some words are wrongly put together while others are wrongly separated. Examples of such are shown below:

$\checkmark$ I saw series of armour tanks from the police. (armouredtanks)

- The Punch news paper reported the crisis. (newspaper)

$\checkmark$ I raised [sic] to the maingate. (main gate)

Pronunciation problems could account for the above errors. The wrong amalgamation may possibly emanate from the way the students pronounced the words. For instance, the absence of ed in armour and its separation from tanks show the weakness in the students' pronunciation. Maingate should have been written as two words since main is used as an adjective qualifying gate as in other phrases like outer gate and inner gate. Even if the student had used it as a compound name, it should have taken a hyphen.

\subsection{Analysis of the Errors of the 500 Level Students}

Tense errors (75\%) form the bulk of the errors made, followed by punctuation (57.5\%), spelling was (45\%), concord (32.5\%), and non-universal abbreviations (2.5\%) as presented in Table 2.

Table 2: Classification of 500 Level Agriculture Students’ Errors

\begin{tabular}{lccc}
\hline Type of Error & $\begin{array}{c}\text { Number of } \\
\text { Students }\end{array}$ & $\begin{array}{c}\text { Frequency } \\
\text { (F) }\end{array}$ & \% \\
\hline Tense & 40 & 30 & 75 \\
Punctuation & 40 & 23 & 57.5 \\
Spelling & 40 & 18 & 45 \\
Concord & 40 & 13 & 32.5 \\
Abbreviation & 40 & 1 & 2.5 \\
\hline
\end{tabular}

The ordering of the errors, with tense right at the top shows that the students have not mastered the syntax of the language of expression (English). Examples of tense errors identified are:

- It can used it effectively to solve the problem. (can be used)

- It immediately fruiting at may be 1-2 years. (It may immediately fruit between one and two years)

- These cultural practices includes... (include)

- Good quality beans can be achieve through good fermentation. (can be achieved)

- There might have being a distance outbreak on it farm. (been)

- This however is only good to cocoa plantation that has not reach the economic stage. (has not reached)

- The require quantity of the require fertilizer can also heep... (required)

- The use of copping and use of budding or chryppons and water sprout. (note that this was written as a sentence)

- Therefore, one of the basic reason why cocoa beans processing is...(reasons)

The tense error identified can also be categorized as secondary grammatical type. Noticeable from the errors is that necessary inflections marking tense in verbs are absent.

The concept of time and verb forms were not understood and were not shown in the constructions. The inflection on the verb which can also be determined by aspect is also seen not to have been used in the examples given above. 
Aspect and tense are two inseparable parts. An attempt to separate them creates difficulties that mar comprehension. As L2 learners of English language, even at 500 level, tense error is still evident. Reasons for this may be as a result of poor foundation in learning the syntax of the language and the inability to determine the correct verb complementation.

As shown in the Table 2, punctuation error ranks second. A total of $57.5 \%$ of the students made punctuation errors. These include wrong use of the marks or their absence, in some cases, wrong capitalization in the middle of sentences and the use of small letters at the beginning of sentences. The wrong use or absence of punctuation marks hinder understanding and pose a great constraint to reading and comprehension. From the corpus, examples are written below:

- to crown it all*스 government should help the farmers involved in cocoa plantation $\underline{-}$

- also Disease causing organisms must be employed...

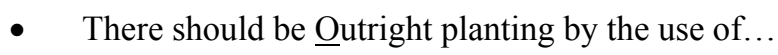

- As a beneficiary of the course $\_$II will do the following 1

- $\quad$ it affects the pod and within $4-18$ days $\_$...

- This is $\_$however $\_$faster and may be more effective.

- If cocoa plantation is dying $\Lambda$ it may be as a result of the following;

- This is necessary for the dying cocoa plantations" to pick up.

- the asexual reproduction. is still candle under research.

*Note that $\_$signifies omission of a punctuation mark

The commonest punctuation error noticed is the arbitrary use of capitalization within a sentence, followed by the absence of comma as a means of separating clauses. Wrong use of capitalization might be due to lack of knowledge but most often, it is as a result of carelessness. Many students break the rule of capitalization at the beginning of the sentence or paragraph. As for the absence of comma, fundamentally, it may be inadequate knowledge of when it should be used.

Spelling error formed about $45 \%$ and is placed third in the ordering of the errors. Likely reasons for spelling errors are fundamentally connected to wrong pronunciation which cannot be separated from faulty listening (Sotiloye 2007). Most words are written as pronounced. The moment a learner perceives and pronounces it wrongly, he writes wrongly. Examples from the corpus are as shown below:

- Soil improvement should be done by application of fertilizer at the appropriate ratio or recommedation. (recommendation)

- The economic life sperm of cocoa ranges from 25 to 40 years. (span)

- Good management technique should be embrraced, such as fungicide and usuage to control weed. (embraced; usage)

- There is need for adaptation to the specific enviroment. (environment)

- This is much important in other of presentation. (order)

- Adequate effective control of pest and disease management through the use of verious pesticides. (various)

- Therefore,... fermentation is protection from indiscriminate germination of embrayo (embryo)

Other examples of spelling error associated with inability to distinguish stress patterns on verbs and nouns are as follows:

- I will advice that they should rejuvenate the crop. (advise)

- This could be practiced. (practised)

- There should be adequate mulching practises.(practices)

- Also the practise of pruning should be taken seriously.(practise)

Malapropisms are also identified in the errors. This is as a result of confusing two words that are pronounced almost alike but with difference in spelling and probably meaning:

- $\quad$ Outwright replanting of old moribund plantation with new cultivars is desired.(outright) 
- It is good to safe the cocoa plantation.(save)

- In order words, they need to be replanted.(other)

Other errors are omission of letters and wrong doubling of letters. Examples are:

- Goverment can do this. (Government)

- $\quad$ Rejuvenate the old stock through copping(coping)

- $\quad$ Agicultural funds and capital must be provided to farmers.(Agricultural)

- I will use organic mannure to improve the soil.(manure)

- The finacial implication is very enormous.(financial)

- Land availability is one of the problems millitating against interested people.(militating)

The effect of these errors, classified as mechanical inaccuracy, is enormous as it puts off the reader and sometimes reduces comprehension.

Concord error constitutes $32.5 \%$. The manifestations of the error are related to the syntax of the language. It revolves round the agreement among the various parts of a sentence. A look at the errors identified from the corpus shows a disagreement between the subjects and verbs of the sentences. Examples of such are shown below:

- This aim at prevension ( $\mathrm{sic}$ ) of spread of diseases. (aims)

- Many plantations has gone to extinction where necessary.(have)

- Cocoa beans with $2 \%$ level of impurity is classified as grade one.(are)

- Chipon are used effectively.(is)

- The required nutrient are thereby released.(is)

- Cocoa production involve maximum amount of water.(involves)

- these includes...(include)

These are errors of subject and verb agreement that is, using singular and plural with incorrect verb forms. Concord errors of shift in number, resulting in wrong use of demonstrative determiners with nouns are identified below:

- If this few points or suggestions of mine can be put into practise [sic]... (these)

- The solutions to these problem include the following (this problem/these problems)

- $\quad$ This old trees are bad / some of this objectives are...(This old tree/These old trees; these objectives)

- Most of these farmer... (these farmers)

Using singular demonstrative determiner for plural nouns could also be traced to pronunciation problem. The inability to use correct determiner shows weakness on the part of the student in differentiating between the short and long high front vowel / i / and / i: /

The error of use of abbreviation in the formal write-up is $2.5 \%$. This is a manifestation of students' carelessness or laziness. The note-taking skill of abbreviation is transferred into formal writing. The effect of abbreviation on comprehension may be grievous. For instance in, inj. the plantation with life by manuring..., (inject) the abbreviation inj. (inject) is not universal and so understanding is hampered.

\section{Comparison of Error Types of 100 and 500 Levels Agriculture Students}

A difference is noticed in the order of the types of errors made by the 100 and 500 levels students as revealed in the Table 3 
Table 3: Comparison of Error Types of First and Final Year Students' Writing

\begin{tabular}{|c|c|c|c|c|c|c|c|c|c|c|c|c|c|c|}
\hline \multirow[t]{3}{*}{ Levels } & \multicolumn{14}{|c|}{ Types of Error } \\
\hline & \multicolumn{2}{|c|}{ Spelling } & \multicolumn{2}{|c|}{ Tense } & \multicolumn{2}{|c|}{ Concord } & \multicolumn{2}{|c|}{ Punctuation } & \multicolumn{2}{|c|}{ Abbreviation } & \multicolumn{2}{|c|}{ Preposition } & \multirow{2}{*}{\multicolumn{2}{|c|}{$\begin{array}{c}\text { Wrong } \\
\text { Amalgamation }\end{array}$}} \\
\hline & & & & & & & & & & & & & & \\
\hline & $\mathrm{F}$ & $\%$ & $\mathrm{~F}$ & $\%$ & $\mathrm{~F}$ & $\%$ & $\mathrm{~F}$ & $\%$ & $\mathrm{~F}$ & $\%$ & $\mathrm{~F}$ & $\%$ & $\mathrm{~F}$ & $\%$ \\
\hline 100 & 45 & 56.25 & 30 & 37.5 & 26 & 32.5 & 23 & 28.75 & 10 & 12.5 & 10 & 12.5 & 3 & 3.75 \\
\hline 500 & 18 & 45 & 30 & 75 & 13 & 32.5 & 23 & 57.5 & 1 & 2.5 & - & - & - & - \\
\hline
\end{tabular}

For the 100 level students, the order is from spelling (56.25\%), tense $(37.5 \%)$, concord $(32.5 \%)$, punctuation $(28.75 \%)$, abbreviation (12.5\%) while for 500 level students the order is tense $(75 \%)$, punctuation $(57.5 \%)$, spelling (45\%), concord (32.5\%), and abbreviation (2.5\%). The order shows that in 500 level students' writing, tense is most problematic while spelling is the most difficult area for 100 level students.

As revealed in Table 3, there are non-consequential abbreviation and no wrong amalgamation errors in 500 level whereas they are $5 \%$ and $12.5 \%$ respectively in 100 level students' writing. The absence of these errors among 500 level agriculture students' writing points to an improvement in their writing, which shows a better mastery of the demands of formal academic writing.

That both 100 and 500 level students manifest some problems in writing shows that both groups of students need help. First year students have just finished the only course in English and Communication Skills in the university while the 500 level students had gone through it about four sessions before then. The findings in the study underscore the fact that the course should not stop in the first session in the university curriculum and this supports Adogwa (1992:62) whose findings revealed the "persistence of three broad categories of grammatical errors namely structural, lexical, and mechanical" leading to a conclusion that "the one year of formal English instruction has not significantly improved the students' performance in grammar", and Bodunde (2005) which came up with a revelation that even students advocate for more years of ECS. The course should be extended, to at least the third year, so as to adequately take care of seemingly difficult areas of the language.

\section{Hypothesis Testing}

The null hypothesis states that 'there is no significant difference between the grammatical errors committed in the writing of first and final year Agriculture students'.

Table 4 shows the results.

Table 4: T-Test Analysis of Writing Errors of First and Final Year Agriculture Students

Independent Samples Test

Assumptions=Equal variances assumed

\begin{tabular}{|c|c|c|c|c|c|c|c|c|c|}
\hline \multirow{3}{*}{$\begin{array}{l}\text { Dependent } \\
\text { variables }\end{array}$} & \multicolumn{5}{|c|}{$\begin{array}{l}\text { Levene's Test } \\
\text { for Equality of } \\
\text { Variances }\end{array}$} & \multicolumn{4}{|c|}{ t-test for Equality of Means } \\
\hline & \multirow[b]{2}{*}{ F } & \multirow[b]{2}{*}{ Sig. } & \multirow[b]{2}{*}{$\mathrm{t}$} & \multirow[b]{2}{*}{ df } & \multirow{2}{*}{$\begin{array}{l}\text { Sig. } \\
\text { (2-tailed) }\end{array}$} & \multirow{2}{*}{$\begin{array}{l}\text { Mean } \\
\text { Difference }\end{array}$} & \multirow{2}{*}{$\begin{array}{l}\text { Std. Error } \\
\text { Difference }\end{array}$} & \multicolumn{2}{|c|}{$\begin{array}{l}95 \% \text { Confidence Interval } \\
\text { of the Difference }\end{array}$} \\
\hline & & & & & & & & Lower & Upper \\
\hline errors & .692 & .425 & .519 & 10 & .615 & 4.00000 & 7.70158 & -13.16018 & 21.16018 \\
\hline
\end{tabular}

The result of the t-test shows a non-significant difference. The null-hypothesis is therefore accepted. It is an indication that both sets of students have not fully mastered the usage of grammatical structures of English and the rubrics of writing. It could also be inferred that there has been minimal transfer of the knowledge gained in the ECS to writing in their disciplines. These findings call for an extension of ECS to enable the students have varied writing exercises as advocated in some previous studies (Adogwa, 1998 and Bodunde, 2005). 


\section{Implications of Findings on Effective Teaching of English and Communication Skills in Second Language Situation}

This study has shown that students, as also reported by Daras and Subramaniam (2009) for Malaysian students in English L2 situation, have problems with almost every aspect of grammar -tense, punctuation, spelling, concord, abbreviation, preposition and word amalgamation. The implication of these findings on Use of English course content is enormous. In general, speech work has to be included in the course content and should be specially taught. This is so because evidences of wrong pronunciation are obvious in the identified wrong spellings, punctuation and concord. In particular, there is need for Contrastive Analysis (CA) of English and indigenous languages in order to identify the points of similarity and difference. The assumption of this kind of analysis is that, point of difference will be areas of potential difficulty in the learning of any of the two contrasted languages. Its order of operation from phonetics, phonology, morphology to syntax will help to make predictions on what the learners will find difficult or easy. For instance, as shown in this study, a Yoruba learner of English language finds it difficult to distinguish between / $\mathrm{h} /$ and / $\mathrm{i} /$ sounds as in:

$\begin{array}{cccc}\text { heat } & \text { instead of } & \text { eat } & \\ \text { hall } & \text { “ } & \text { “ } & \text { all } \\ \text { hill } & \text { “ } & \text { “ } & \text { ill } \\ \text { hat } & \text { “ } & \text { “ } & \text { at }\end{array}$

Hence, the /h/ sound is introduced into words which ordinarily do not have the sound causing the learner to write the words wrongly. This is corroborated in Akeredolu-Ale (2005).

Also, short and long vowels should be specially set out in the course content because they affect both spelling and concord. For instance, /i/ and /i:/, /u/ and /u:/ in:

$\begin{array}{llll}/ \mathrm{i} / & / \mathrm{i}: / & / \mathrm{u} / & / \mathrm{u}: / \\ \text { this } & \text { these } & \text { full } & \text { fool } \\ \text { pick } & \text { peak } & \text { pull } & \text { pool } \\ \text { wick } & \text { weak } & \text { could } & \text { cool }\end{array}$

Dark and silent letters should also form a subset of the speech work content. The relationship among tense, mood and aspect needs to be carefully presented and taught. Particular attention should be paid to the use of to- infinitive in relation to aspect. This will put paid to the hyper use of past verbs as demonstrated in the identified errors. The inclusion of the above specified areas in ECS has a great implication on the lecturers. The bulk of the work in improving the writing skills lies on them. Carrying out a CA on English and the indigenous languages demands dedication, interest, commitment, hard work and determination. The interest of the students must be enlisted. This can be achieved by dividing the class into manageable sizes to allow for interactive sections between teachers and learners. It will also give room for effective evaluation on the part of both the teachers and learners.

The findings also imply that undergraduates need be more sensitive in their writings and be deliberately interested in correct pronunciation. The use of the dictionary would be of tremendous help in improving student' speaking and writing skills. They should be prepared to work harder when more contact hours are introduced.

On the part of the university administration, the Curriculum Committee needs to revisit the duration of ECS. Bodunde (2005) discovers students' preference for a three session ECS course instead of one. Elongation of the course may also affect the other courses in the curriculum. Effort should be made to harmonise the duration of the course and the other courses in the curriculum.

An enabling environment conducive for the teaching and learning processes should be made available in second language situation. Facilities like language laboratories that would arouse interest in language learning and teaching should be provided. Employment and training of more teachers of English with linguistic and pedagogical background should be enhanced.

Taking a cue from the success recorded in a socio-cultural exchange face-to-face tandem programme reported by Alonso (2006) in the teaching and learning of English in a Spanish secondary school setting, the suggestion of an immersion system in which our students learn in a native L2 environment would have been most appropriate. However, apart from being an expensive 'expedition', it is unlikely that it would receive acceptance in a non-conventional university like our case study where the students' and authority's attitude to the Use of English course is lackadaisical. The method will be very suitable and is highly recommended for institutions with core 
English Departments as a replica of the 'one-year abroad' for students of French language who, as part of graduation requirements, spend a year in a French-speaking country.

\section{Conclusion}

Studies on the writing of undergraduates by other researchers like Aborisade, and Oguntuase (Federal University of Technology Akure), Adelabu (Federal University of Technology, Markurdi), Onukaogu (Obafemi Awolowo University, Ile-Ife), though each using parameters totally different from the present research, also arrive at the same conclusion that students, especially those in the science and technology classes perform poorly in English language use. Tense, spelling, and punctuation errors are identified in all the studies; however, the present research contributes to the effort in solving the problem in students' writing by identifying other problematic areas like wrong use of preposition, wrong word formation, and lack of concord. It also establishes wrong pronunciation as the bane of some of the identified writing errors. It shows the relationship between speaking and writing skills since good writing depends on the mastery of the grammar of the target language which is evidenced in good expression. Teachers of English should, therefore, make concerted effort to teach the speaking skill extensively. Insights into these language learning problems identified provide information on trouble-spots in language learning and these can be used in the preparation of effective teaching materials. This may require their coming together at a forum in which their teaching methodology and the curriculum would be reviewed.

\section{References}

Abdullah, M.R.T., Bakar, Z.A., Ali, R.M., Yaacob, R.A., Abdur-Rahman, M.A., Embong, A.M., \& Amar, A. Z. (2011). Writing Strategies of Malaysian ESL Undergraduate Engineering Learners. International Journal of Engineering \& Technology IJET-IJENS, 11(2), 2110802-3939.

Aborisade, P. (2003). An analysis of Some Discourse Features in Biological Science Research Reports: Implications for EST Course. ELTT: A Journal for Teachers of English and Communication Skills, 2(2), 7-13.

Adelabu, B., \& Fadimu, T. (2004). An Examination of Written English Errors Among First Year Undergraduates in a Nigerian University ELTT. A Journal for Teachers of English and Communication Skills, 3(1), 54-61.

Adogwa, T. O. (1992). A Comparative Study of Grammatical and Discourse Errors of Senior Secondary Three and First Year Undergraduate Students Unpublished M.Ed in TESL Dissertation Ahmadu Bello University, Zaria, Nigeria.

Agustin Llach, M.P. (2012). Lexical Errors and Accuracy in Foreign Language Writing. The Modern Language Journal, 96(3), 463 - 464. http://doi:10.1111/j.1540-4781.2012.01367_2x

Akeredolu-Ale, B. (2005). Remedying some Basic Pronunciation Errors through Perception and Production Drills: A Teacher' ELTT: A Journal for Teachers of English and Communication Skills, 4(1), 51-59.

Alonso, A. C. (2006). Teaching English to Mixed-Ability Secondary Students through e-Tandem. Retrieved from www.aul.es/odisea/Odisea07_Canga

Ancker, W. (2000). Errors and Corrective Feedback: Updated Theory and Classroom Practice. Forum, 38(4), 20-25. $\mathrm{http} / /$ exchanges.states.gov//forum/

Bodunde, H.A. (2005). Students' Perception on Effective Teaching and Learning of English and Communication Skills: An Approach to Needs Analysis. ELTT: A Journal for Teachers of English and Communication Skills, 4(2), 21- 28.

Bodunde, H.A. (2008). School Location and Proficiency in Oral English. ASSET Series C, 3(1), 80-85.

Bodunde, H.A., \& Olanipekun, F.A. (2009). Peer Critiquing as an Effective Strategy for Teaching Writing. African Research Review, 3(5), 386-472.

Crompton, P. (2011). Article Errors in the English Writing of Advanced L1 Arabic Learners: The Role of Transfer. Professional Teachers' Article, 50, 1-33. Retrieved from www.asian-efl-journal.com

Daras, S., \& Sabramaniam, K. (2009). Error Analysis of the written English Essays of Secondary School Students in Malaysia: A Case Study. European Journal of Social Sciences, 8(3), 483-495.

Ellis, R. (1996). Second Language Acquisition Research and Language Teaching. Oxford: Oxford University Press. http://dx.doi.org/10.1016/0889-4906(93)90027-L 
Huckin, T. N., \& Oslen, L. A. (1984). The Need for Professionally Oriented ESL Instruction in the United States. TESOL Quarterly, 18, 273 -294. http://dx.doi.org/10.2307/3586694

Jekins, S., Jordan, M. K., \& Weiland, P.O. (1993). The Role of Writing in Graduate Engineering Education: A Survey of Faculty Beliefs and Practices. English for Specific Purposes, 12(1), 51-67.

Lengo, N. (1995). What is an Error? English Teaching Forum, 33(3), 20 -24. http//exchanges.states.gov//forum/

Oguntuase, F. (2003). Assessing Written Communicative Competence and Productive Functions of 100 Level Engineering Students. ELTT: A Journal for Teachers of English and Communication Skills, 2(2), 32-38.

Onukaogu, C. (2005). Literacy for Empowerment: Making Things Happen in the Use of English Program. Keynote address presented at the $3^{\text {rd }}$ Annual Conference of National Association Teachers and Researchers of English as a Second Language (NATRESL) $5^{\text {th }}-7^{\text {th }}$ Oct., 2005.

Ortmeier-Hooper, C., Cox, M., Jordan, J., \& Schwartz, G. (eds.) (2010). Reinventing Identities in Second Language Writing. NCTE Press.

Osagbemi, M. I., \& Bodunde, H.A. (1998). Teachers' and Students' Perception of the English Language Skills Needs and Agricultural Students of Ahmadu Bello University, Colleges of Agriculture. Nigerian Journal of Technical Education, 15(2), 132-140.

Shuh, M. (1986). Content-based Approaches to Testing Academic Writing. TESOL Quarterly, 20, 617-648. http://dx.doi.org/10.2307/3586515

Snow, M. A., \& Brinton, D. M. (1988). Content-based Language Instructions: Investigating the Effectiveness of the Adjunct-Model. TESOL Quarterly, 22, 553-574. http://dx.doi.org/10.2307/3587256

Sotiloye, B.S. (2007). The Challenges of Teaching Oral English in a Nigerian Non-Conventional University: A Teacher's Experience. ASSET Series C, 2(1), 88-95.

Sotiloye, B.S., \& Bodunde, H.A. (2013). Necessary Herculean Task: Re-writing the English Orthography. International Journal of Humanities and Social Sciences, 3(7), 290 - 297.

Spack, R. (1998). Initiative ESL Students into the Academic Discourse Community: How Far Should We Go? TESOL Quarterly, 22, 29-51. http://dx.doi.org/10.2307/3587060

Titchenelle, K. (2011). The Three Most Common English Language Errors made by Non-English Speakers. Abacus English Editing Services, 20. Retrieved from www.abacus-es.com

Vaughan, A. (2011). 'Vaughans Common English Usage Errors' In Vaughan's Summaries General Knowledge Reference. Retrieved from www.vaughans-1-pagers.com 